\title{
Human Resource Development in Tourism Industry in India: A Case Study of Air India Ltd., New Delhi
}

\author{
Nafees A. Khan
}

\begin{abstract}
He purpose of Human Resource Development is to improve the capacity of the human resource through learning and performance at the individual, process and organizational levels. By applying a well-ordered and professional HRD approach to work in the protected areas field, the skills, knowledge and attitudes of park personnel will be enriched and this overall quality of work performed will improve. There are a number of problems and constraints, which concern the human resource development in the Tourism Industry, viz., shortage of qualified manpower; shortage of tourism training infrastructure and qualified trainers; working conditions in the Tourism Industry; and lack of proper strategies and policies for human resource development. The present study is an attempt to analyze the HRD initiatives of Tourism Industry with special reference to Air India Ltd. to enhance and sharpen the capabilities of its employees. The study also identifies the need of the Air India to incorporate the spirit of HRD in day to day functioning by utilizing the all possible human resource systems and mechanism to the organization.
\end{abstract}

\section{KEY WORDS}

Human Resource Development, Air India Ltd., Capabilities,

Productivity, Training and Development. 


\title{
Human Resource Development in Tourism Industry in India: \\ A Case Study of Air India Ltd., New Delhi
}

\author{
Nafees A. Khan
}

RESUMEN

El propósito del Desarrollo del Recurso Humano es mejorar la capacidad de estos recursos mediante el aprendizaje y el rendimiento de cada individuo por medio de procesos y niveles organizados. Para la aplicación de un mejor orden y profesionalización del Desarrollo de Recursos Humanos en el acercamiento al trabajo en las áreas terreno; las habilidades, los conocimientos y aptitudes del personal serán enriquecidas y estas crearan una mayor calidad en el trabajo. Existe un numero de problemas y contradicciones, las cuales conciernen al desarrollo de los recursos humanos en la industria del turismo, como son, la escases de mano de obra calificada, la escases de infraestructura en formación turística, las condiciones de trabajo en la industria turística, la falta de estrategias y políticas para el desarrollo de los recursos humanos. El presente estudio es un intento de análisis del Desarrollo de los Recursos Humanos en las iniciativas de la industria turística, con especial relevancia en Air India Ltd, para mejorar y afinar las capacidades de sus empleados. El estudio solo identifica la necesidad de Air India en incorporar, un espíritu de DRH en el día a día, la

funcionalidad en la utilización de los recursos humanos en todos los sistemas y mecanismos de la organización.

\section{PALABRAS CLAVE}

Desarrollo de los Recursos Humanos, Air India Ltd, Capacidades, Productividad, Capacidades y Desarrollo. 


\section{SIGNIFICANCE OF THE STUDY :}

The importance of Human Resource Development for Tourism Industry is increasingly being realized. There is a need to mobilize the human resource with the purpose to enable them to participate in the task of organizational development and nation building. Mobilization would include the need to develop the human resource, their skills, knowledge, attitudes, so that they can achieve competently the pre-determined goals. Obviously the efficient and professional management is pre-requisite of successful tourism development. Having equal importance, however, is the quality of staff training, which is often relatively neglected during the early stages of tourism sector development. Tourism basically being a service business, a developing destination must take the necessary steps to build a pool of efficient trained people to fill various jobs, which will be created subsequently. A variety of jobs will have to be created to look after and manage various tourist services. Special attention, therefore, will have to be given to the needs of manpower and personnel to be trained and rendered qualified for the various tourism professions. Special care has to be taken to ensure that there is expansion of facilities and services. In case of a developing country, it will also be appropriate to study at this stage the volume of manpower required for activities complementary to accommodation industry in general and service sector particular.

Dr. Nafees A. Khan,

Ph.D., D.Litt. (Tourism) Reader

Department of Commerce

Aligarh Muslim University, Aligarh-202002, (U.P.) India

e-mail: nafeesakhan12@rediffmail.com
Inspite of having a lot of tourism potentials India's share of global international tourism is relatively small in volume about $0.40 \%$ of world tourism. The greatest thrust to tourism will come through human resource development in our country. We would have skilled persons to handle this industry right from the level of waiters to executive level and in case of Air India Ltd. ground duty staff to flying staff. ${ }^{2}$

While planning for human resources development, programmes should be established to screen and train prospective employees so that they could 
acquire both attitudinal as well as technical skills. Attitudinal characteristics contribute to an employee's success in tourism position and include pride, flexibility, adaptability and judgement. Technical skills required for equipment operation and maintenance, financial management, food and beverage, and personnel management etc. In order to determine the need for various personal required, a staff planning exercise may be done. This involves a series of steps, which include job analysis, preparing job description, job specifications and preparing staff forecasts. This sequence of activities leads to a detailed forecast of exactly what types of persons, with what specific qualifications and skills will be required at all major facilities within the tourist destination. All this helps in determining the development of requisite education and training programmes within the country for local residents. This will also help in determining whether there is a need for trained personnel from other countries and also whether local people are to be sent for training elsewhere. ${ }^{3}$ 


\section{LITERATURE REVIEW:}

The successive paragraphs present a comprehensive review of literature on the subject matter. In 1982, Rao, T.V. conducted a Survey of HRD practices in Indian industries. The survey reveal that only 17 out of 53 companies had formal policy focusing on HRD. All in all HRD appeared to be becoming a significant aspect of work life in many organizations.

Another survey was carried out by Rao, T.R. to judge HRD climate in Indian organisations. The survey revealed that the general climate was not very conducive to HRD due to general indifference of employees to their own development. The top management in most organizations were not making sufficient efforts to improve the quality of work life.

Rao, P. Punna and Reddy M. Sudarshan in their compiled and edited book entitled "Human Resources Development : Mechanisms for Extension Organisations" (2001) have mentioned the importance of Human Resource Development for Agriculture Extension. They realised that there is a need for fresh look at efforts to build the capacity and capability for HRD in the emerging areas.

Agarwal, Nair Banerjee in his book entitled "Human Resource Management" (2004) has mentioned that the purpose of this book is to assimitate new insights from human resource management and behavioural sciences into established concepts. In order to make this more interesting, the authors have utilized the ocncept of formulating the plan to divide the book concerts into small units. Attempts have been made to stress empirically to the practical problems

Prasad, L.M. in his book entitled "Human Resource Management" (2003) has tried to place proper emphasis on the human resources of the organization. It presents the most recent developments in the field and tries to relate how these developments are relevant to Indian Companies. It incorporates the human resource management practices being followed by the leading Indian Companies in their respective fields. It has failed to focus on HRD and tourism.

Gupta, Shishi K. and Joshi, Rosy in their book entitled "Human Resource Management" (2004) have laid emphasis only to the effectiveness of Management of Human Resources. 
Kaushal, H. in his book entitled "Human Resource Development" (2004) has made an attempt at making good this vital deficiency of workable case studies in management. A serious attempt has been made to cover all aspects of HRD theory through the case studies and has not included tourism industry.

Reddy, Sumati in her edited book entitled "E-Learning and Technology: New Opportunities in Training and Development" (2003) has highlighted how distance training and education helps organizations to meet the challenge of organizational change reach competitive standards and achieve organizational goals. Distance and online training is considered as an investment $n$ people which helps in meeting pre-determined objectives.

Asia Pacific and Training Institutes in Tourism (APETIT), United Nations Environment Programme (UNEP), International Labour Organization (ILO), World Tourism Organization (WTO) and the World Travel and Tourism Council (WTTC) etc., for development of human resource to achieve productivity at maximum level in travel and tourism industry have not made in-depth countryspecific study pertaining to HRD and productivity in India's tourism sector, particularly after the implementation of the policy of economic liberalization.

The author has consulted a number of national and international journals such as Journal of Hospitality and Tourism Management, School of Tourism and Leisure Management, the University of Queens land; Tourism Recreation Research, Journal of Tourism and International Research, Journal of Travel and Tourism, Centre for Mountain Tourism and Hospitality Studies, H.N.B. Garhwal University, Srinagar, International Journal of Management and Tourism, Jodhpur Rajasthan, Vol. 1, No. 2, Oct-Dec. 1992; Journal of Annals of Tourism Research, vol. VIII (1991), Department of Habitational Resources, University of Wisconsin-Stout, USA, Discover India published by Media Transasia Limited, Hong Kong; Tourism India, India tourism Magazine, Thiruvanathapuram, Kerala, Vol. 7, No. 4, Aug. 2004; Tourism Development Journal, Vol. 1, No. 1, 2003, Institute of Vocational Studies, H.P. University, Shimla; Asia Pacific Education and Training Institute of Tourism (APETIT) News, Vol. 3/2 June-July, 2004, IITTM, Gwalior and World Tourism Organisation (WTO) Report, 2003; Report, National Committee on Tourism (1988) and has also searched relevant ongoing 
projects on internet. The author has also consulted a number of M.Phil. dissertations and Ph.D. theses on Human Resource Development.

The foregoing comprehensive review of literature on human resource development in India, it peters out that very few researches are found to be relevant. However, there is a dearth of research studies on the development of human resources in Tourism Industry particularly in post liberalization era. The present study is an endeavour of the author to present the varied dimensions and facets of developing the human resources in Tourism Industry with special reference to Air India Ltd., New Delhi.

It is, nevertheless, not out of place to mention that above refereed literatures on HRD in Tourism Industry have niggardly addressed to HRD in Tourism Industry. Author has made an endavour to bring in account a comprehensive study with regard to HRD in Tourism Industry. The case study of Air India Ltd., New Delhi would successfully represents the concept and applicability of HRD in Tourism Industry in India.

The foregoing comprehensive review of literature on HRD in Tourism Industry, it peters out the following scope and objectives. 
SCOPE OF THE STUDY:

The study is based on field survey, which has been conducted in January 2007. The perspective background of the study refers to the time span from 2004-2006. On the basis of statistics collected from field survey, tables have been prepared and suitable tools have been applied (referred famework of the study).

\section{STATEMENT OF THE PROBLEM AND EMERGING ISSUES:}

- The quality and efficiency of services is the primary concern of tourism industry. In order to achieve this, each of the components of tourism industry requires trained /skilled manpower. The travel and tourism industry is really as good as only its people, and it is the people that make the real product. The right person in the right job is essential for the success in any business. In travel agencies, tour operations units, hotels, restaurants, motels, resorts and similar businesses, this factor is particularly important. Thus the need to develop the required human resources in various segments of the tourism industry in general and Air India in particular has become imperative.

- There are a number of problems and constraints, which concern the human resources development in the tourism sector, viz., shortage of qualified manpower, shortage of tourism training infrastructure and qualified trainers, working conditions in the tourism sector, and lack of proper strategies and policies for human resources development.

- A well educated and well trained tourism executive, as also the workers at different levels of work, always prove effective. Therefore, there is need to employ well-educated and well trained tourism personnel for achieving higher productivity.

- Tourism Industry utilizing the services of well trained staff are successfully generating resources by selling tourism products in cost-effective packages, reaping higher gains; while those Tourism Industry which do not utilize the sources of well-educated and trained human resource, are placed in the second fiddle, suffering with a comparative lack of power to compete. 
- The resource generation ability of those Tourism Industry which utilize the services of well educated and well trained human resources, will be definitely higher.

- Numerous decision-making activities, having their bearing upon planning, control, investment, product-mix, etc., stand hampered by a growing shortage of relevant, reliable and timely statistical data on both the micro and macro levels. This too necessitates the involvement of well-educated and well-trained personnel in the Tourism Industry.

- Pressures for more efficient allocation and utilization of organizational resources will require the use of far more effective personnel in tourism industry as a whole and its subsectoral activities adding to higher productivity.

- Tourism Industry in India suffers from several weaknesses both in qualitative and quantitative terms.

It is with the above-mentioned imperatives that this study has been undertaken. 
OBJECTIVES OF THE STUDY:

I) To impart knowledge and develop skills oriented to the nature and needs of the Tourism Industry for present and future needs.

II) To develop the individual intellectually as well as materially to enable him to lead a fuller life by developing his/her capacity to learn and earn.

III) To enhance the contribution, which individuals can make in the collective tourism, endeavour, which is needed to enlarge the availability of, services which the nation, as a whole needs.

IV) To acquire/sharpen capabilities required to perform various obligations in the Tourism Industry and the tasks and functions associated with their present or expected future roles.

V) To develop an organizational culture in which superiors subordinate relationship, team work, and coordination among different sub-units are strong and contribute to the organizational wealth, dynamism, professional well-being, motivation and pride of the employees in Tourism Industry.

VI) To assess the growth in productivity of Tourism Industry in India.

VII) To prescribe a package of recommendations meant for the government and the Tourism Industry both to make the industry more effective and viable. 


\section{HYPOTHESES}

Ho1 It is premised that Tourism Industry can not achieve its effectiveness with the help of HRD philosophy and approach. Nevertheless, the alternate hypothesis suggests that the tourism industry can achieve its effectiveness provided due care is taken to plan, develop and monitor the HRD systems, keeping in view the organizational and industry requirements.

Ho2 Tourism Industry in India has been developing in a lop-sided manner as a result of which it has failed to develop its proper organizational structure in which superior sub-ordinate relationship; co-ordination among different sub-units and team work has not become stronger. This has been adversely affecting the achievement of organizational goals.

Ho3 People join organisations with certain motives, viz., adequate pay and perks, job security, career advancement and satisfaction of psychological and social needs. The management of Tourism Industry in India has not been paying due attention to these factors.

Ho4 There has not been so encouraging the overall performance as regards higher productivity of Tourism Industry in India. 
FRAMEWORK OF THE STUDY:

\section{(a) Research Design and Methodology :}

It has been be the endeavour of the author to make an empirical study, by analyzing and critically examining the relevant statistics, collected from primary as well as secondary sources. Primary data have been collected by using structured questionnaire, personal interviews, discussions and observations.

Secondary sources include published and unpublished sources. Published sources are newspapers, reports of WTO, ITDC, and official publications of national and international tourism bodies including Central and State Governments. Unpublished sources viz., the records maintained by the Government and private hotels, studies undertaken by research institutions, scholars, executives and economists have served the purpose.

The research design and methodology with respect to the sample size, its composition and susceptibility for the selected statistical tools and procedures have been strongly influenced by the inherent characteristics of the respondents working in Air India Ltd. which has been undertaken as case study.

\section{(b) Non-Parametric Statistical Analysis :}

To Conclude data in a meaningful manner, to find out perceptions and opinions and to study the uniformity in the views of various respondents, chi-square (2) test has been applied. The ' $t$ ' test has also been applied for.

\section{(c) Sample :}

100 employees (not below the rank of Assistant Managers and supervisory levels) of Air India Ltd., New Delhi have been selected. The sampling method has been devised as to ensure adequate representation for the entire population with regard to human resource development.

\section{(d) Questionnaire Design :}

Pilot survey has been undertaken for pre-testing the questionnaire. Questionnaire has been edited in the light of the results of the pilot survey. The questionnaire includes 28 statements (referred 
to Appendix-I) relating to the importance of human resources in the eyes of management, to impart knowledge and develop skills, organizations recruitment policy, selection procedure, to development the individual intellectually as well as materially, to enhance the contribution which individuals can make in the collective endeavour, properly planned, developed and monitored the HRD system, consultancy rules/guidelines and policy, to develop an organizational structure in which superior sub-ordinate relations become stronger, recognition of adequate pay, perks and other financial benefits of the employees by the organizations to develop managerial capabilities of management staff, to organize frequent career counselling and short duration programmes, to review the status of growth in the productivity of tourism organizations, mechanism adopted by the organizations, to reward for any good work done, to satisfy with the rewards and incentive schemes provided by the organization, to make efforts to identify and utilize the potentials of the employees, performance appraisal reports, to create organizational culture within the organization and finally to achieve organizational effectiveness.

Scaling: Three scales i.e. Agree, Disagree, and No Response statements have been consideration.

\section{Limitation of the Study :}

(I) Some of the conclusions are based on the estimates, assumptions, observations and informal interviews.

(II) Sample size remain medium. 


\section{A CASE STUDY OF AIR INDIA LTD., NEW DELHI:}

\section{Financial Position of Air India Ltd.:}

The annual turnover of Air India Ltd., during 1996-97 was Rs. 3817.78 crores (one crores $=10$ million). Now a days, the financial position of Air India is not strong. It is incurring heavy losses for the last four years. Its net worth over the last four years has decreased from Rs. 1375 crores to Rs. 393 crores, Rs. 1,000 crores in assistance. Its estimated losses this year is in the region of Rs. 185 crores and the accumulative losses well over Rs. 1,000 crores. Air India has managed to cut its losses from record of Rs. 413 crores to a more manageable Rs. 140 crores for the year ended 31st March, $1999 .{ }^{4}$

Further, rising fuel costs and payment of wage arrears have led Air India to incur a net loss of Rs 447.93 crore in last fiscal.The loss was primarily due to higher operating costs and lower revenues for 2006-07.

Fuel costs accounted for $35 \%$ of the total operating cost that rose by Rs 386 crore to Rs 3,530, up almost $13 \%$. Besides, the carrier had an outgo of Rs 425 crore on account of payment of wage arrears of the staff that had been pending since long. ${ }^{6}$

The revenues of the national carrier also fell by Rs 329 crore to Rs 5,360 crore. While the airline had to pay Rs 200 crore on borrowings to fund its fleet acquisition programme, the interest on its working capital also rose significantly by Rs 155 crore.?

The Government of India has taken a decision in principle to merge the two airlines i.e. Air India and Indian Air Lines in order to enable them to achieve synergies and reduce costs. It has to be a complete merger creating one culture, one company.

The new entity formed after the merger of state run carriers Air India and Indian will be in place soon. The Proposed merger would run the combine entity into a mega carrier with about 130 aircraft to take on the major global carriers, specially those operating in the region. Globally mega mergers have taken place in the recent past including KLM - Air France and Lufthansa - Swiss Air. 
In the past decade, the financial position of two carriers had been adversely affected due to intense competition and their inability to induct new fleet.

It is estimated that the decision of the merger of two airlines would result in the net benefit of Rs. 600 crores at the end of 3rd year of merger.

The technical and procedural formalities for merging the two airlines would be under one company with one name, one brand, one logo, one code and single financials.

The merged carrier has ordered 111 new aircraft- 43 from the Airbus Industrie for erstwhile Indian and 68 Boeings for the former Al. The former Indian also suffered a a loss or Rs 275 crore in the last fiscal. From this financial year, books of both the airlines, including Air and Air India Express, would be merged to prepare the accounts of the new holding firm, National Aviation Company. The losses were more than they had expected and depreciation was too high. The Board had decided on various steps to cut operating costs by $3.5 \% .^{8}$

In order to make case study of Air India Ltd., New Delhi, the questionnaire is designed to find out the opinions of the employees (not below the rank of Asstt. Managers and Supervisory level) regarding the Human Resource Development in Tourism Industry in India. The questionnaire consists of 28 statements which are related to human resource planning, recruitment and selection, training and development, performance appraisal, career development, counseling, reward system and organizational culture and effectiveness. The purpose of the present questionnaire is as to how train and develop the persons in the Air India Ltd. both in the qualitative and quantitative terms; thereby to utilize their potentialities for enhancing productivity to help improve job conditions and quality of their work life. 


\section{Analysis and Interpretation :}

The previous hypotheses have been tested with use of appropriate statistical tools such as chisquare $\left(x^{2}\right)$. The ' $\mathrm{t}$ ' test has also been made use of.

\begin{tabular}{|c|c|c|c|c|c|c|c|}
\hline \multicolumn{2}{|c|}{$\begin{array}{l}\text { Agreed } \\
\text { statements (A) }\end{array}$} & \multicolumn{2}{|c|}{$\begin{array}{l}\text { Disagreed statements } \\
\text { (B) }\end{array}$} & \multirow{2}{*}{$\begin{array}{l}\text { No } \\
\text { response } \\
\text { state- } \\
\text { ments }\end{array}$} & \multirow{2}{*}{$\begin{array}{l}\text { Total } \\
(\mathrm{A}+\mathrm{B}) \\
=\mathrm{C}_{1}\end{array}$} & \multirow{2}{*}{$\begin{array}{c}\chi^{2} \text { value }= \\
\sum \frac{(\mathrm{O}-\mathrm{E})^{2}}{\mathrm{E}} \\
\left(\mathrm{A}_{1}\right)\end{array}$} & \multirow{2}{*}{$\begin{array}{c}\chi^{2} \text { value }= \\
\sum \frac{(\mathrm{O}-\mathrm{E})^{2}}{\mathrm{E}} \\
\left(\mathrm{B}_{1}\right)\end{array}$} \\
\hline $\begin{array}{l}\text { Obser } \\
\text {-ved } \\
\text { Freq. } \\
\text { (O) }\end{array}$ & $\begin{array}{l}\text { Expetd. } \\
\text { Freq.(E) }\end{array}$ & $\begin{array}{l}\text { Obser- } \\
\text { ved } \\
\text { Freq. } \\
(\mathrm{O}\end{array}$ & $\begin{array}{l}\text { Expctd. } \\
\text { Freq.(E) }\end{array}$ & & & & \\
\hline 90 & 59.43 & 8 & 38.57 & 2 & 98 & 15.724 & 24.229 \\
\hline 65 & 57.61 & 30 & 37.39 & 5 & 95 & 0.947 & 1.459 \\
\hline 55 & 60.04 & 44 & 38.96 & 1 & 99 & 0.422 & 0.651 \\
\hline 50 & 60.04 & 49 & 38.96 & 1 & 99 & 1.678 & 2.586 \\
\hline 45 & 60.64 & 55 & 39.36 & 0 & 100 & 4.036 & 93.431 \\
\hline 55 & 60.64 & 45 & 39.36 & 0 & 100 & 0.525 & 93.451 \\
\hline 40 & 58.83 & 57 & 38.17 & 3 & 97 & 6.024 & 9.283 \\
\hline 60 & 60.04 & 39 & 38.96 & 1 & 99 & 2.472 & 3.811 \\
\hline 75 & 60.04 & 24 & 38.96 & 1 & 99 & 3.728 & 5.745 \\
\hline 55 & 58.83 & 42 & 38.17 & 3 & 97 & 0.248 & 0.383 \\
\hline 65 & 58.22 & 31 & 37.78 & 4 & 96 & 0.789 & 1.217 \\
\hline 60 & 58.83 & 37 & 38.17 & 3 & 97 & 0.023 & 0.036 \\
\hline 55 & 58.43 & 43 & 38.57 & 2 & 98 & 0.330 & 0.509 \\
\hline 70 & 59.43 & 28 & 38.57 & 2 & 98 & 1.879 & 2.895 \\
\hline 55 & 57.61 & 40 & 37.39 & 5 & 95 & 0.118 & 0.152 \\
\hline 65 & 59.43 & 33 & 38.57 & 2 & 98 & 0.521 & 0.903 \\
\hline 80 & 59.43 & 18 & 38.57 & 2 & 98 & 7.118 & 10.968 \\
\hline 75 & 57.61 & 20 & 37.39 & 5 & 95 & 5.247 & 8.086 \\
\hline 45 & 58.83 & 52 & 38.17 & 3 & 97 & 3.249 & 5.007 \\
\hline 40 & 60.04 & 89 & 38.96 & 1 & 99 & 6.688 & 10.306 \\
\hline 80 & 59.43 & 18 & 38.57 & 2 & 98 & 7.118 & 10.968 \\
\hline 60 & 58.83 & 37 & 38.17 & 3 & 97 & 0.023 & 0.036 \\
\hline 50 & 57.61 & 45 & 37.39 & 5 & 95 & 1.005 & 1.550 \\
\hline 40 & 58.83 & 57 & 38.17 & 3 & 97 & 6.024 & 9.283 \\
\hline 55 & 58.83 & 42 & 38.17 & 3 & 97 & 0.248 & 0.383 \\
\hline 70 & 58.83 & 27 & 38.17 & 3 & 97 & 2.122 & 3.270 \\
\hline 45 & 58.22 & 51 & 37.78 & 4 & 96 & 3.001 & 4.625 \\
\hline 55 & 58.83 & 42 & 38.17 & 3 & 97 & 0.248 & 0.383 \\
\hline $\begin{array}{c}\mathrm{T}_{1} \\
1655\end{array}$ & & $\begin{array}{c}\mathrm{T}_{2} \\
1073\end{array}$ & & & $\begin{array}{c}\mathrm{T}_{3} \\
2728\end{array}$ & $\begin{array}{r}\text { Total of } \\
=3\end{array}$ & $\begin{array}{l}\left.A_{1}+B_{1}\right) \chi^{2} \\
.804\end{array}$ \\
\hline
\end{tabular}

Table 1

Air India Limited, New Delhi

Chi-square Value $\left(x^{2}\right)$

Source: Data collected through questionnaire

Note: No response statements have been excluded while calculating $c 2$ value. 


$$
\begin{aligned}
& V \quad=\quad(r-1) \quad x \quad(c-1) \\
& \text { Column }=2 \text {, rows }=28 \\
& =\quad(2-1) \times(28-1) \\
& =\quad 27 \times 1=27 \\
& \text { Expected frequency }=\left(T_{2} \times C_{1}\right) / T_{3} \\
& \text { where r refers to rows and c refers to columns. } \\
& \left.x^{2} \text { (calculated value }\right)=380.85 \\
& x^{2} 0.05,27=40.113 \text { (table value) }
\end{aligned}
$$

Since the calculated value of $x^{2}$ is much more than the table value, hence the hypothesis $\mathrm{H}_{0}$ (null hypothesis) is rejected and $\mathrm{H}_{1}$ (alternative hypothesis) is accepted.

Thus, the result of experiment does not support the hypothesis. Hence, the researcher concludes that factors framed affect the overall improvement of the functioning of Air India Limited.

Keeping in view the objectives of the study, respondents' opinion regarding the Human Resource Development in Air India Ltd. have been presented and analysed in Table 1. It is evident that majority of the employees agree with the statements of questionnaire that human resource is to be considered as an extremely important factor for productivity. The majority of the respondents agree with the same. It shows that opinion of the respondents is not equally distributed. It can be concluded that they feel that the top management do not treat human resources more politely as it is one of the important factors of production. Tables also show that a few respondents are uncertain about their opinions regarding various statements of questionnaire.

Most of the employees feel that there is need to re-structure their organizations and train and develop the human resources according to its pre-determined objectives. They feel that their potentialities are not fully utilized for enhancing productivity of both the organizations. While HRD has been helping Air India Ltd., the overall performance as regards higher productivity has not been so encouraging. The main reason is conflict between employees and the top management in the organization, which leads to strike and unrest among the employees. Further, organisational 
culture created within the organizations is not conducive for sustainable development.

$90 \%$ of the respondents of statement No. 1 are agree with this statement, whereas $65 \%$ are agree with the statement No. 2, 55\% respondents are agree with the statement No. 3, 50\% of the respondents are agree with the statement No. 4, while $45 \%$ of the respondents are agree with statement No. 5, and so on.

On the other hand $8 \%$ of the total respondents are disagree with the statement, $30 \%$ of the respondents do not agree with the statement No. 2 and $44 \%$ of the respondents do not agree with the statement No. 3 and so on. (Please refer to Table No. 01). 


\section{FINDINGS:}

Respondents' opinion regarding human resource development in Air India Ltd., has been presented and analyzed in table -1 and it is found that majority of the employees agree with the question of the questionnaire that the human resource is to be considered as an extremely important factor for productivity. They feel that top management do not treat human resources more politely as it is one of the important factors of production.

Most of the employees feel that there is need to re-structure the organizations of Air India Ltd. and train and develop them according to its pre-determined objectives. They feel that their potentialities are not fully utilized for enhancing productivity of this organization. While HRD has been helping Air India Ltd., the overall performance as regards higher productivity has not been so encouraging. The main reason is the conflict between employees and the management, which leads to strike and unrest among them.

Further, organizational culture created within the organizations are not conducive for sustainable development.

To conclude data in a meaningful manner and to find out the perceptions and opinions Chisquare (c2) test is used in the table-1. There are 28 parameters in the table, which measures these opinions effectively. Statistically there is no difference between the expected and the observed frequencies. According to the results of chi-square, it is observed that the calculated c2 values for these 28 variables are greater than the table value (Table value of Chi-square for 2, c2 $0.05=40.113$ ) and are significant at 0.05 percent level of significance. Thus the hypothesis $\mathrm{Ho}$ is rejected and $\mathrm{H} 1$ (alternative hypothesis) is accepted. Hence, there is a significant difference among respondents over the opinion about HRD in Tourism Industry in India. Therefore, the author conclude that factors framed affect the overall improvement of the functioning of Air India Ltd. Thus, there is a need for the improvement in the functioning of Air India Ltd., New Delhi. 


\section{CONCLUSION, SUGGESTIONS \& RECOMMENDATION:}

Tourism is a human experience, a social experience, a geographical phenomenon, a resource value, and a business industry. It is a major social phenomenon of the modern society with enormous economic consequences. Its importance as an instrument for economic development and employment generation, particularly in remote and backward areas, has now been well recognized the world over. The industry today is globally recognized as a major economic contributor and employment generator. The investment flows into this field are constantly on the increase.

The tourism industry faced with various challenges in the field of human resources, one of the crucial issues in this regard is the quality of manpower. The industry is vitally faced with the demand for qualified quality personnel.

Today, human resource planning is considered as the way management comes to grasp the illdefined and tough-to-solve human resource problems facing an organization.

The role of HR manager is very crucial in selecting and recruiting the right kind of people who can be an asset for the tourism sector.

The training and development plans are aimed at developing talents to perform effectively in the present and future higher levels on more challenging work situations.

The success of an organization depends on its ability to affect continuous improvement and provide quality products and services to its customer. This will require every personnel in the organization to possess the requisite knowledge, skill and attitude. For the purpose of determining training requirements, two levels of supervision could be identified. Each level of supervision should have a curriculum that addresses competencies required at that level.

Work can be a significant source of satisfaction if opportunities are provided for the recognition and meeting of employee's needs. 
Rewards for an employee including both monetary compensation and non-monetary recognition must met his basic needs and conform to the three parameters of external equity, internal equity and individual equity.

Organizational culture is extremely important to create an environment of respect for each other build team spirit, provide enlightened leadership and capable supervision, and show that employees are wanted.

The developing countries must first develop the human resources in order to develop the Tourism institutional structure in which technological innovation can occur on a large scale. Economic development can succeed only when the environment as a whole is conducive to change and innovation at all levels and on all fronts especially in Tourism Industry. This will require educated masses, literate and national masses.

The strategies supported to achieve the goal of human resources development in Tourism Industry include more open government, more transparent and accountable public administration and development of energetic entrepreneurship in developing countries and further liberalization of markets and goods, capital, technology and tourism products. This would require joint action programmes. A new vision for global co-operation for the next century is needed.

It has become imperative that Tourism Industry should concentrate on HRD system for grooming. HR in such a manner so as to flourish and achieve international competitiveness in tourism.

The Tourism Industry faces with various challenges in the field of human resources; one of the crucial issues in this regard is the quality of manpower. The industry is vitally faced with the demand for qualified quality personnel.

The Government of India has shown some interest, though obviously not enough, in the promotion of Tourism Industry over the years, the Government has realized the importance of the skilled manpower in the field at different level to train and develop human resources. 
The government should set up a high power committee consisting of Human Resource Development professionals, professionals from the Tourism Industry, prominent economists and intellectuals to study and assess various aspects of HRD and conclude on a National Tourism Policy on HRD.

Inadequate infrastructure is another factor of much concern for Indian tourism. As matter of fact, one of the major setbacks that the Department of Tourism has suffered is that its demand for substantial investments amounting to Rs. 45,000 crores which involves centre, states financial institutions and private sector to develop tourist infrastructure. Modernisation of Delhi and Mumbai airports is needed urgently. It s believed that the Department of Tourism has been unable to convince the Finance Ministry and the Planning Commission to grant adequate resources for the development of infrastructure. It is imperative on the part of the Department of Tourism to fight all the way to acquire those sources for integrated infrastructure development.

For the upgradation of Human Resources there should be a career planning, career development and career counseling mechanism to make employees aware of the general phases of their growth and development.

It is the right time to accord the status of tourism in priority due to increase in tourist arrivals and the socio-economic benefits of the tourism phenomenon.

It is recommended that the Government of India should form a 'HRD Board', which should encourage the researches upon increasing potentiality of human resources. It should take many productive and aggressive steps for the promotion of HRD. The need of the hour is to tackle grassroots realities of HRD and then take some harsh measures to infuse a new blood in Air India Ltd. 


\section{REFERENCES:}

- $1 . \quad$ Rao, V.S.P. (2004), Human Resource Management, Excell Books, New Delhi.

- 2. Report (2004-05), Ministry of Tourism, Government of India, New Delhi.

- 3. Rudrabhasavaraj, M.N. (2004). Human Resource Management Manual, Himalaya Publishing House, Mumbai.

- 4. $\quad$ PTI Report, The Time of India, New Delhi, October 12, 1999, p.6.

- 5. $\quad$ UNI Report, The Times of India, New Delhi, May 28, 1998, p. 6.

- 6. UNI Report, "Merged IA, AI will be ready in four months", The Times of India, New Delhi, March 3, 2007, p. 15.

- $7 . \quad$ UNI Report, "Al, Al merger with in 6 months, The Times of India, New Delhi, April 6, 2007, p. 18.

- 8. Economic Survey (2005-06), Ministry of Finance, Government of India, New Delhi, p. 156.

- 9. Seth, Pran Nath and Bhat, Sushma Seth (2004), An Introduction to Travel 7 tourism, Sterling Publishers Pvt. Ltd., New Delhi.

- 10. Sinha, P.C. (2004), Tourism Transport and Travel Management, Anmol Publications Pvt. Ltd., New Delhi.

- $\quad 11 . \quad$ Tourist Statistics, WTO (2004-05), Madrid, p. 28.

- $\quad$ Raj Aparna (2004), The travel Industry - Emerging Human Capital Attracting the Talent and Keeping it too", Study material for FDP, supplied by ITTM, Gwalior, pp. 133-134.

- 13. Anand, Byas, "Merger plan of IA \& Al finalised", The Times of India, New Delhi, October 13, 2006.

- $\quad$ w. $\quad$ wWw.Indianairlines.nic.in

- $15 . \quad$ www.hrplanning.com

- $16 . \quad$ www.indiatourism.com

- $17 . \quad$ wWw.travelindia.com 


\section{APPENDIX-I}

Instruction: Please Put Tick Mark (Ö) in the relevant boxes.

Statements:

1. Does top management believe that human resource is an extremely important resource and whether it is to be treated more politely?

$$
\text { Agree Disagree No Response }
$$

2. Does top management need to impart knowledge and develop skills, oriented to the nature and needs of the Air India Ltd. for present and future requirement?

$$
\text { Agree Disagree No Response }
$$

3. (I) Does the organization's recruitment policy aim at the long-run development of potential employees?

Agree Disagree No Response

(II) If agree, who frames it?

Ministry of Civil Aviation

Air India Ltd..

Air India Ltd. in consultation with the relevant

organization

Any other viz., the Professional HRD organizations.

4. Does top management consider appropriate selection as an important function of HRD?
Agree Disagree
No Response

5. Is the present selection procedure adopted by the Air India Ltd. is considered beneficial :

(a) By the employees:

Agree Disagree No Response

(b) By the organization:

Agree Disagree No Response

(c) By both (a) and (b) :

Agree Disagree No Response

6. Does the management of Air India Ltd. think to develop the individual intellectually as well as materially to enable him/her lead a fuller life by developing his/her capacity to learn and earn?

Agree Disagree No Response

7. Does the management make efforts to enhance the contribution, which individuals can make in the collective endeavour of the organization?

112 Human Resource Development in Tourism Industry in India : A Case Study of Air India Ltd., New Delhi 


\section{Agree Disagree No Response}

8. Has Air India Ltd. properly planned, developed and is monitoring the HRD system keeping in view the organizational requirements?
Agree Disagree
No Response

9. (I) Do you have consultancy rules/guidelines and policy in place?

(a) All the above :

Agree Disagree No Response

(b) Rules and Guidelines:

Agree Disagree No Response

(c) Only Policy :

Agree Disagree No Response

(II) If any, how many types of consultancies are allowed?

Individual

Institutional

Collaborative

Any other type (please specify).

10. (I) Do you take steps to develop an organizational structure in which superior sub-ordinate relationship and co-ordination among different units, become strong for achievement of organizational goals?

\section{Agree Disagree No Response}

11. Does management of Air India Ltd. recognize the importance of :

(I) Adequate pay, perks, and other financial benefits of the employees?

Agree Disagree No Response

(II) Job security and career advancement of the employees

Agree Disagree No Response

(II) Both (i) and (ii) above

Agree Disagree No Response

12. (I) Is there adequate emphasis on developing managerial capabilities of management staff of Air India Ltd. through training?

Agree Disagree No Response

(II) Training arrangement:

1. On the Job

Agree Disagree No Response

2. In organization's own training school.

Agree Disagree No Response 
3. In other reported training establishments :
Agree Disagree No Response

13. (I) Does Air India Ltd. organize frequently career counseling and short-duration programmes for updating the knowledge and skills managers/supervisors/grass root level employees?

\section{Agree Disagree No Response}

14. (I) What is the status of growth in the productivity of Air India Ltd.. for the last 5 years?
Agree Disagree
No Response

15. Is there any mechanism in Air India Ltd. to reward for any good work done or any contribution made by the employees for their motivation?
Agree Disagree
No Response

16. Are employees (flying and ground duty staff) of Air India Ltd. satisfied with the rewards and incentive schemes provided by the organization?

(I) Flying staff :

Agree Disagree No Response

(II) Ground duty staff :
Agree Disagree
No Response

17. Does the management of Air India Ltd. make efforts to identify and utilize the potential of the employees?
Agree Disagree
No Response

18. Does the top management spend a considerable part of its time and money to ensure development of its employees?
Agree Disagree
No Response

19. Does performance appraisal reports in this organization are based on objective assessment and adequate information, and not on subjective opinion?

$$
\text { Agree Disagree No Response }
$$

20. Do you feel satiffied at your present post in all respects:
Agree Disagree
No Response

21. Does management recommend a change in the present assignment of the employees for the purpose of gaining varied experience?

\section{Agree Disagree No Response}

22. Do you concur with the assessment of the Reporting Officer of Air India Ltd. in respect of Appraisal factors (viz. Decision making, power of analysis, knowledge, Personality, Human Relations, Resourcefulness, Communication, results produced). 


\section{Agree Disagree No Response}

23. Do you concur with the assessment of the reporting officer regarding promotability, training needs and development plans?

Agree Disagree No Response

24. Are there any limiting factors which possibly hinder the future advancement of the employees?
Agree Disagree
No Response

25. Do you consider your employees suitable in all respects to hold independent charge of a post of representational nature?
Agree Disagree
No Response

26. Does your organization has any major significant achievement/patents/MoU/transfer of technology as a result of interaction with other Tourism?

(I) Indian (specific airlines)

Agree Disagree No Response

(II) Foreign or local basis

Agree Disagree No Response

(II) If agree, at the national or international level? National International

27. (I) Is organizational culture created within Air India Ltd. to help keep it dynamic ?

Agree Disagree No Response

(II) If agree, what practices in your view would help sustain the work culture in your organization?

\section{Infusing the mission spirit among employees \\ Responsible top management practices \\ Socialization}

Any other type viz., synchronization of individual and

organizational goals.

28. Does Air India Ltd.. intend to achieve organizational effectiveness i.e. inspiration to achieve goals, through higher production, cost reduction, higher profitability, growth and diversification?

Agree Disagree No Response 


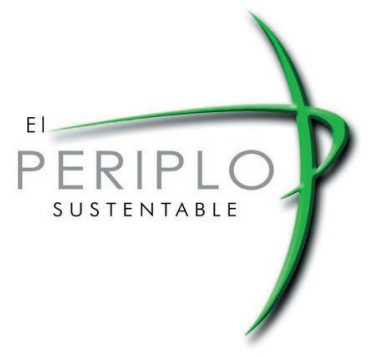

FICHA BIBLIOGRÁFICA:

Nafees A. Khan. Human Resource Development in Tourism Industry in India : A Case Study of Air India Ltd., New Delhi.

El Periplo Sustentable. Espacio de análisis y reflexión sobre Turismo Sustentable. México: Universidad Autónoma del Estado de México, julio de 2008, núm. 14

$<$ http://www.uaemex.mx/plin/psus/rev14/articulo_05.pdfs.

[ISSN: 1870-9036]. 